\title{
THE INFLUENCE OF USING CHORAL READING TECHNIQUE TO THE ELEVENTH GRADE STUDENTS' READING MASTERY AT SMA NEGERI 1KASIMBAR
}

\author{
Andi Aldi \\ Muhammad Ihsan \\ Fitriningsih \\ Rasmi \\ Study Program of English Tadris Faculty of Tarbiyah and Teacher Training \\ State Islamic University (UIN) Datokarama Palu \\ E-mail: andialdian@gmail.com
}

\begin{abstract}
This paper focuses on the using of choral reading technique to the eleventh grade students' reading mastery at SMA Negeri 1 Kasimbar. The writer applied quasi experimental research design and need pre-test and post-test to both experimental and control class. The pre-test was to know the level of students' reading mastery ability before giving treatment while the post-test was used to know the result after giving treatment. There was a significant difference score of the post-test of the experimental class (1.495) and the control class (1.235). The level of significance was set up 0,05 with 40 degree of freedom $((\mathrm{df})=\mathrm{Nx}+\mathrm{Ny}=21+21+40)$. The result of data analysis indicates that tcounted $(3,729)$ which was higher than table, it means that the hypothesis of the research was accepted. Thus, there was significant influence of using choral reading technique to the eleventh grade students at SMA Negeri 1 Kasimbar.
\end{abstract}

Keywords: Improving, Reading, Choral Reading 
Datokarama English Education Journal Vol. 2 No. 2, 2021

\section{Background}

Reading is one important skill in learning English especially in schools. For beginners, reading is important to increase their knowledge. Reading is a process of interpreting the message. A good reader must have a good ability in order to know the meaning and the main point of the text. In order to accomplish success one needs to have a good reading and reading comprehension. Without these skills, students will struggle to grow academically as reading is the foundation to all academic subjects such as history, science and also influences the students' ability to write.

Reading also is one of the skills that has to be mastered by students. The students will learn new knowledge and new information by reading. They are able to have good mastery in reading because it helps them understand the information that they want to get. If they do not, they find it difficult to get the message from the text. Reading is not only about fluency but also how the students understand the information conveyed by the writer. They should know the meaning of the text in order to make them know the passage.

According to David Nunan, reading is a set of the skills that involves making sense and deriving meaning from the printed word. ${ }^{1}$ Beside that, most of the readers can get much information based on what they read such as health, technology, art, politic, culture, sport, etc.

In SMA Negeri 1 Kasimbar, the students almost never read English text because they feel difficult to understand the texts. Because of it, they are still low in mastering in English mainly in reading mastery. Reading mastery lessons incorporate accuracy and fluency instruction by daily oral reading, repeated readings, and partner

\footnotetext{
${ }^{1}$ David Nunan, Practical English Language Teaching.(New York: McGraw Hill Companies Inc ,2005), 69.
}

reading. In the beginning of each lesson, students orally read lists consisting of words that they will encounter in the text for that specific lesson. Students take turns reading parts or all of the reading selection aloud. If a student makes a mistake, he or she is asked to reread the sentence. There is an error limit for each section. If students exceed the error limit, they are required to read the section again for extra practice. In addition, students receive practice with fluency by reading sections aloud with partners. Teachers can monitor students' progress by specific rate and accuracy criteria provided in the program. The level of expectation increases as students' progress through the different levels of reading mastery. ${ }^{2}$

The students also have less vocabulary and it is difficult to pronounce the English text. It is one of the problems of the students. They should practice reading English texts to make their reading mastery better.

The writer found problems in English, such as the students at SMA Negeri 1 Kasimbar, especially grade XI IPA that do not interest learning their reading subject more. The students feel difficult to understand the reading texts, so they feel bored and lazy to learn English reading subject.

The reading ability of students especially grade XI IPA is still so low, due to several aspects, among others in terms of students, media, strategies, and infrastructure. Grade XI IPA students of SMA Negeri 1 Kasimbar on average do not have supporting books/reading material, reading with the index finger followed, reading still stammers, students read carelessly, almost all of the sentences that are not read according to the

\footnotetext{
${ }^{2}$ Sara J. Gervase. "Reading Mastery: A Descriptive Study of Teachers Attitudes and Perceptions Towards Direct Instruction. A Thesis, (Bowling Green University Graduate Student, 2005), 14
} 
correct rules. The media used is still monotonous, not yet varied, causing students not be interested in attending the lesson. During the learning process, many students only talk to their friends, some play smartphones, dumbly, get sleepy, make the subjects underestimated. The use of learning techniques is still not appropriate. So that the material delivered by the teacher is not about the target.

Most of the students are silent, indifferent to the lessons delivered by the teacher. They are preoccupied with their own activities, even some students are sleeping. The available infrastructure is still limited so that not all students can use it simultaneously at the same time, for example an English dictionary and LCD/projector. Students do not have student worksheet books let alone other reference books. So, learning depends only on the teacher in front of the class. This has caused the students' reading mastery to not reach a standard competency.

Based on the results of learning that have been done so far, the competencies that are expected cannot be achieved due to the application of techniques that are still not appropriate and the use of media that is not appropriate. Therefore it is necessary to apply choral reading techniques through the explanation text as the media. So students become more interested, creative, innovative to follow the lessons so that they can develop their fluency and reading mastery.

Creative and innovative learning is an effort to realize meaningful learning for students according to the expected goals in each subject. In this study, the writer can formulate that reading skills can be improved by using choral reading technique through the explanation text as the learning media.

In choral reading technique, students read a passage in unison. The leader is usually the teacher or another model reader. This technique is more interesting for students. The students can practice to read together with their friend. Poor readers as well as shy ones can use the whole-group format to avoid humiliating corrections while they gain confidence in themselves. The obtrusive student may be tempered through the same whole-group format, which discourages that students from showing off.

Hasbrouck states, choral reading is reading aloud in unison with a whole class or group of students. Choral reading helps build students' mastery, fluency, self-confidence, and motivation. ${ }^{3}$ Choral reading involves students and teachers simultaneously reading the text together. During choral reading, it is the teachers' job to set the pace of the reading. When the teacher reads, students read along with him or her, imitating his or her inflection and tone of voice. It provides students with supported word recognition and provides them with access to the text. There may be variations in choral reading to develop students' reading mastery. So, the more students practice reading, the more they master vocabulary. When the students have many vocabularies, it will make them easier to comprehend the text. So, choral reading technique is the technique that can help students to improve their reading mastery.

What was stated by Wood, that choral reading means read aloud with the same text at the same time. According to Wood, by reading together in unison, and the child hears our voice, it is automatic guide and support in reading. Meanwhile according to Stoodt, Amspaugh, \& Hunt, uses one choice with various choral reading methods, so that students learn about various ways to express meaning. By choosing wrong one method of choral students can express meaning correctly because reading aloud together makes it easy for students to grasp the, meaning.

\footnotetext{
${ }^{3}$ Hasbrouck, J. Choral Reading. from https://www.readingrockets.Org/strategies/choral_readi ng. (2006).( accessed on 06 June, 2016).
} 
So by reading unanimously together with the whole class or student groups can help students' reading mastery, fluency, confidence, and motivation. Because by reading aloud, students who usually feel nervous when reading will have direct support.

In this research, the writer uses a kind of text namely explanation text as the media. In which the students not only read but understand the aim of the text. An explanation text is a non-fiction text that is used to describe how or why things happen. It usually includes a sequence of events (explaining how) and provides reasons for a process or phenomenon (why). ${ }^{4}$

The purpose of this study is to find out the steps of the model choral reading technique through explanation text as learning media to improve the activeness and learning outcomes of class XI IPA students of SMA Negeri 1 Kasimbar, and develop the students' reading mastery of class XI IPA through the application of learning models choral reading technique explanation text as learning media at SMA Negeri 1 Kasimbar.

Based on background above, the writer was interested to investigate about the effect of choral reading in students' reading comprehension entitled "The Influence of Using Choral Reading Technique to the Eleventh Grade Students' Reading Mastery at SMA Negeri 1 Kasimbar".

\section{Literature Review}

\subsection{The Nature of Reading Mastery}

\section{a. Reading}

Reading is one of requirements that enhance individuals' ability of adaptation to social life and fulfill their needs. People using their reading skills from childhood to the end of life. It is an active process that builds new

\footnotetext{
${ }^{4}$ Mahrukh Bashir, Bahasa Inggris: SMA/ MA/ SMKJ MAK KelasXI, (Jakarta: PusatKurikulumdanPerbukuan, 2014), 101.
}

learning by combining new information with the current knowledge. ${ }^{5}$ Reading as one aspect of the four language skills, plays an important role in language teaching. Said to be important because, in Addition to teaching listening, speaking and writing. Reading skill is one very powerful tool for obtaining a wide range or specific information, including science and technology. Every day we read books, magazines, advertisements, paper, etc. To get information from a book, we need to comprehend it well.

From reading, students gets many benefit. Reading is not only a source of information but also as a means of consolidating and extending one's knowledge of language. I.S.P nation says that reading is a source of learning and enjoyment. With reading, the learners can learn new vocabulary and grammar. Reading can also be a source for enjoyment and a way of gaining information in the world. Zuchdi and Budiasih also has explained that:

Reading is one type of written language skills who are receptive. Called receptive because by reading a person will obtain information, acquire science and knowledge and new experiences. All of which is obtained through reading would allow a person to enhance the power of thought, sharpen vision, and broaden their horizons. ${ }^{6}$

${ }^{5}$ Hülya Kodan "The Effects of the Methods of Choral, repeated and Assisted reading on the Reading and Reading Comprehension Skills of Poor Readers",conducted under the supervision of Hawaii Akyol. Online published (Turkey: Bayburt University, Education Faculty, Departement of Primary Education, 2017), 160.

(Learning

${ }^{6}$ Zuchdi and Budiasih, The Nature of Reading,

http://jundanjin.blogspot.com/2011/01/nature-of-

reading.html, (accessed on December 06, 2019)

Media, 
Datokarama English Education Journal Vol. 2 No. 2, 2021

For adult, being able to read individuals the opportunity to become more autonomous, to make choices, to evaluate different points of view, to make informed decisions and to gain access to new idea or new points and to analyze information. It is clear that the children's purpose in reading are different from adults. Most of the children read the text for pleasure.

As explained above, reading can be easier to do if we do it as a pleasure activity. Reading is a process. Kalayo and fausan says that reading is interactive process that goes on the between readers and the text. Resulting comprehension. According to David Nunan, reading is a fluent process of readers combining information from a text and their own background knowledge to build meaning. It means that we can build meaning of text if we are combining our background knowledge and information from the text. Ann browns also says that reading is an active and complex process which draw on the application of a number of skills and knowledge about language and print. It means that we read the text, we should apply our skills to gain the meaning from the text.

\section{b. Models of reading}

Most models maybe placed in one of three classes, as follows:

1) Top-down Model

According to J. Charles, "top down model mean that Approaches emphasis the importance of these schemata, and the reader's contribution over the incoming text ". 7 In topdown model, the peruser's earlier information and intellectual and semantics skill assume key jobs in the contraction of significance.

The end is in the top-down model, the reader assumes a functioning job all the while understudy attempts to anticipate the perspective of the content dependent on

${ }^{7}$ J. Charles Alderson, Assesing Reading,(New York: Cambridge University Press, 2000), students own earlier information to get the data from the content.

2) Bottom-up Model

Bottom-up model, means that approaches are serial models, where the reader begins with the printed word, recognizes graphic stimuli, decodes them to sound, recognizes words and decodes meanings. ${ }^{8}$ It means that when people are reading, they pick up the graphic or symbol information from the text (letters, words, phrases,sentences). Next syntactic and semantic processing will be happened. As the result, the written text is understood by the reader.

3) Interactive Model

Interactive models are not merely are compromise Between bottom-up and topdown model. Neither the bottom up now topdown, is an adequate characterization of the reading process, and more adequate models are known as interactive models. ${ }^{9}$

It means that this model occurs when both of bottom-up and top-down model processes accuracy when the reader read the text.

\section{c. Reading Mastery}

According to Schieffer et al. (n.d.), "Reading Mastery are basal reading programs ( that develop vocabulary, reading skills and strategies through systematic, small steps that make it possible for all students to learn and learn in a timely manner)" $" 10$

Schieffer et al. (n.d.) explain that reading mastery recognizes that a prerequisite to learning to read is oral language skills. Oral language skills necessary to understand what

\section{${ }^{8}$ Ibid, 16. \\ ${ }^{9}$ Ibid., 18.}

${ }^{10}$ Sara J. Gervase. "Reading Mastery: A Descriptive Study of Teachers Attitudes and Perceptions Towards Direct Instruction. A Thesis, (Bowling Green University Graduate Student, 2005), 11 
Datokarama English Education Journal Vol. 2 No. 2, 2021

is spoken, written, and read in the classroom are taught in the reading mastery.

Reading mastery is best used in small group setting, and is often adopted by a whole school. Direct instruction takes place between the teacher and the students. During the initial phases of a lesson, students respond to the teacher as a group. Once the concept or skill is firm, children are called on to respond on and individual basis. Students also do private work in a series of workbooks, designed to consolidate their learning. ${ }^{11}$

Reading mastery targets the development of four reading-related skills. In sequential order:

1) Phonemic Awareness

Students are taught how to segment or break words down in their smaller soundunits. Common, high-frequency letters and sounds are taught how to blend phonemes together to form words.

2) Decoding

Students are then taught to use what they have learned in decoding and spelling words. Reading mastery uses a specific orthography at this stage, designed to aid children with decoding words. The orthography provides visual cues about, for example, which letters are stressed and which are not. It is gradually faded out so that students read conventional letter-formations after having sufficient practice with phoneme awareness.

3) Irregularities

The next step involves teaching sight recognition of common irregular words, i.e those which cannot be decoded phonetically. It involves repetition and practice.

4) Reading Accuracy and Fluency

Students read the text aloud which are primarily composed of words they already know. Students can be constantly monitored

\footnotetext{
${ }^{11} \mathrm{http}: / / \mathrm{www}$. sraonline.com
}

for reading the words with correctly and quickly. ${ }^{12}$

\subsection{Choral reading}

a. Definition

Choral reading technique is a technique for concert reading. According to Sylvia and Sharon, choral reading is reading of text by several students in unison. ${ }^{13}$

According to Freeman, choral reading is also referred to as choral speech, the simultaneous oral reading of material by two or more people, has been reported to be highly effecting in reducing stuttering. ${ }^{14}$

Choral reading is well suited for short story, poetry, rhymes, and dialogues. Choral reading give students the opportunity to try out language. This practice also helps students improve their sight vocabulary and develop oral language skills. ${ }^{15}$ In the other hand, Wood states that choral reading can be an enjoyable and engaging method to employ. Having students read at significant point in a selection can increase suspense or express an emotional reaction intended by the author. ${ }^{16}$

Choral reading is quite rewarding and relatively easy to organize. Students seem to

\footnotetext{
${ }^{12}$ Ibid

${ }^{13}$ Sylvia Linan-Thompson and Sharon Vaughn, Research-Based Methods of Reading Instruction for English Language Learners grades $K-4$ (USA: ASCD, 2007), 152.
}

${ }^{14}$ Kathryn Freeman. Stuttering reduction During Choral Reading, journal of speech-language pathology and audiology. Journal of Speech-Language Pathology and Audiology, Vol .22, No.3, september 1998. 188.

${ }^{15}$ Judie Haynes, Getting Started with English Language Learners, (USA: ASCD, 2007), 83.

${ }^{16}$ Barbara J. Wendling and Nancy Mather, Essentials of Evidence, (Autralia: Wiley, 2008), 38. 
love the challenge of speaking aloud together, and it piques the interest of many students to read additional poetry or to write poetry of their own. It also teaches spoken language skills, such as diction, pronunciation, volume, rate and pitch.

From the definition above, the writer presumed that choral reading technique is reading materials as one with one speaker or more simultaneously. In this technique there is a leader that will guide the text. The leader reads loudly and the other students will follow the leader.

\section{$b$. Types of choral reading}

1) Refrain is one of the most common forms of choral speaking. One person reads the narrative portion of the text while the rest of the class join in the refrain.

2) Unison, calls for the whole group to read the material together, additional sound effects might be incorporate.

3) Antiphon calls for the class to be divided into two or more groups, with each group being responsible for a certain part of the selection.

4) Cumulative choral reading or speaking revers to a method where groups of voices are added to or subtracted from the choral reading. Depending on the message or the meaning communicated by the selection.

5) Solo lines is a type of choral reading where individuals read specific lines in appropriate places throughout the group activity.

6) Line around is more solo work where each line is taken by different person in the group.

Choral reading is reading aloud in unison with a whole class or group of students. Choral reading help builds student's fluency, self-confidence, and motivation. Because students are reading aloud together, students who may ordinarily feel self-conscious or nervous about reading aloud have built-in support. It can provide less skilled readers the opportunity to practice and receive support before being required to read on their own. It provides a model for fluent reading as students listen. It helps improve the ability to read sight word.

Choral reading can use with choose a book passage that the works well for reading aloud as a group; patterned or predictable (for beginning readers), not too long, and it is at the independent reading level of most students. Provide each student a copy of the text so they may follow along. Read the passage of story aloud and model fluent reading for the students. Ask the students to use a marker for finger to follow along with the text as they read. Reread the passage and have all students in the group, read the story or the passage aloud in unison. Purpose: to makes students active participants in the poetry experience. Also helps develop fluency in reading. Rationale: better readers and fluency makes for better comprehension of the text being read.

c. Arrangements

1) Echo reading: the leader reads each line, the group then repeats the line just read.

2) Leader and the chorus reading: the leader reads the main part of the poem, and the group reads the refrain or chorus in unison.

3) Small group reading: the class decide into two or more groups and each group reads one part of the poem.

4) Cumulative reading: one student or group reads the first line or stanza and then another student/group joins in as each line is read.

\section{d. Procedure}

1) Select poem and use the copy to a chart or make individual copies. 
Datokarama English Education Journal Vol. 2 No. 2, 2021

2) Work with students to decided how to decided how arrange the poem for reading.

3) Read with students several times. Emphasize that students should pronounce words clearly and read with expression.

e. The advantages and disadvantages

1) Advantages

Accordingto Yunoeka, there are four advantages cited in the survey above and reiterated below should be just as valid, if not more so, in a group reading setting as in an individual one, consider:

a) Expansion of oral vocabulary-choral reading with a native near-native peacemaking model provides a setting conducive to deriving meanings of unknown vocabulary from the context of the material, especially if the process is repeated several times and key vocabulary words are introduced between readings,

b) Developing awareness of the sounds of the language - the pace making model not only provides an immediate pronunciation for unknown words which is simultaneously produced by the student, but also provides immediate feedback for words which students have mispronounced,

c) Facilitation of chunking of words in meaning full groups - choral reading naturally leads students to read in "chunks", following breaks between the word groups provided by the model,

d) Development of self-confidence - the constant, spontaneous and to a great extent unvarying feedback by the model provides a measure by which students can infer the extent of their own improvement, both in reading speed and understanding. ${ }^{17}$

\footnotetext{
${ }^{17}$ Judy Yoneoka. Choral Reading vs. Individual Oral and Silent Reading: Relative Validity of the Alternatives in the English Reading Classroom.[Electronic Version], Assessed on May 5, 2011, Unpublished), 3.
}

2) Disadvantages

The disadvantages of choral reading

technique are:

a) Choral reading frequently will slow down our reading speed that it always emphasize to improve.

b) The students are reading easy to embarrassed when reading. They will read worse when being corrected by teacher.

c) Compared to conversation and discussion, choral reading has little practical value unless the students will be announced in the future. ${ }^{18}$

\subsection{The use of choral reading technique to} improve students' reading mastery

This technique can be applied in every grade, teacher can choose the appropriate material that can be use to improve students' reading mastery. Moreover, according to Garrett, choral reading provides support for students who may ordinarily feel self-conciuos or nervous about reading aloud in class. ${ }^{19}$ Reading along with more fluent readers enables less proficient readers to be successful with a share text. Choral reading may provide the may provide support necessarily necessary to encourage struggling readers to take risks and build their confidence. When student participate in choral reading on a regular and repeated basis, student will internalize the fluent reading of the text being read and begin to transfer their improving fluency and mastery to other text.

\footnotetext{
${ }^{18}$ Nadia Zorrela "Increasing Students' Reading Comprehension Through Choral Reading Strategy at Seventh Grade of Private Islamic Junior High School Jami'Al Kautsar Tapung Hilir".Online published (Medan: Departement of English Education Faculty of Tarbiyah and Teacher Training State Islamic University of North Sumatra Medan, 2017), 12.
}

\footnotetext{
${ }^{19}$ Laura Garett. Choral Reading Strategy. [Electronic Version] fromhttp://myweb.stedwards./Ed/mikekb/ReadStrong/c horalreading.html. (accessed on May 05, 2011)
} 
Based on the expert above, choral reading technique can decrease students nervous. This technique also increases students confident in reading the material aloud. Then, students can read the material well with good confident.

Choral reading can be an excellent tool for older readers who are not confident but who want to read the good stuff. Children track print as they read, so it can also be a good tool for emergent and beginning readers. This, they can "read" material they cannot read on their own. Choral reading whets their appetite for more reading. It encourages risk taking and builds confidence. It helps build vocabulary as well as comprehension. It also builds classroom community in the same way that singing does. It is excellent for older readers too.

Therefore, choral reading technique is a good technique to improve students' reading comprehension. This technique can increase students vocabulary and students' reading comprehension. It also helps the students to build their confident in reading the text.

In conclusion, choral reading technique is a good tool for students in any grade, from the beginner grade until older readers.

\subsection{Explanation text}

\section{a. The Definition of Explanation Text}

An explanation is one of writing text that has multiple definitions sorted by experts. According to Blake, it is a text which establishes that the phenomenonexists and explains why or how this came about. ${ }^{20} \mathrm{~A}$ similar definition of explanation text is also defined in a national curriculum school book Bahasa Inggris as a non-fiction narrative used to describe natural, social, and scientific

\footnotetext{
${ }^{20}$ Blake, Explanation Texts Structure and Features of Explanation Texts, (Blake Education Fully Reproducible, 2011), 62.
}

phenomena formed. ${ }^{21}$ Based on the description above, the writer can draw a big picture of explanation text: a text which gives the reason 'why' and 'how' the process of events that has no human involved in.

\section{b. The Purpose of Explanation Text}

To explain why and how something in the universe happen is an explanation text's function. The text is more concerned to actions that have scientific and technical processes. In other words, the purpose is to illustrate a series of actions or operations conducing to an end involved in the formation or working of pristine or something that involves a combination of social and cultural factors phenomena. ${ }^{22}$

c. The Schematic Features of Explanation Text

\section{1) Title}

Explanations have a title that provides and drives the reader to the text. This can appear in a sort of forms from a topic that identifies the action to a how and why issue or a problem that is answered by the explanation.

2) General statement

A general statement begins in the first paragraph to introduce or identify the scientific or technical phenomenon. The audience gets a brief introduction to the event or thing and an understanding of the type of text that is to follow.

3) Series of sequenced paragraphs

At this stage, students' explanations are producing causal connections as well as consecutive ones. The logically sequenced paragraphs more describe the cause of something rather than concentrating on an

\footnotetext{
${ }^{21}$ Mahrukh Bashir, Bahasa Inggris: SMA/ MA/ SMK/ MAK KelasXI, (Jakarta: PusatKurikulumdanPerbukuan, 2017), 101.

${ }^{22}$ AchmadDoddy, Ahmad Sugeng, and Effendi, Developing English Competencies 3: for Senior High School (SMA/MA) Grade XI of Natural and Social Science Programmes, (Jakarta: PusatPerbukuan, 2008), 52.
} 
Datokarama English Education Journal Vol. 2 No. 2, 2021

object. The explanation order should consist of a series of events, actions, causes, or processes that are the aim of the text type. Actions, causes or events, that link text results in the phenomenon about which the explanation, is written. Events may be associated with period or cause or by both and should be specific and precise, guaranteeing that all components have been involved. Sequences often develop by demonstrating how the events appear over a period of time: this happens and follows the next event. It is important that in addition to investigating the facts, students get the reasons following these facts. Attention should be focused on writing these reasons in their explanations.

4) Labelled diagrams and flow charts

Labelled diagrams and flow charts are an addition that can be used to clarify information or to add additional information not included in the explanation. In the scientific text, specific charts and figures are essential to support them.

5) Concluding paragraph

An optionally final statement can bind the information. An optional concluding statement can tie up the explanation ${ }^{23}$ d. The Types of Explanation Text.

An explanation text has various types as follow:

1) Explaining something-mechanical works

It maybe power-driven demonstrating how a garden engine works, technological about how a computer operates, and natural when illustrating how landslides happen.

2) Explaining things happen

This type explains about why objects and contact something. For example, why bathroom mirrors mist up when somebody showers. ${ }^{24}$

${ }^{23}$ Blake, Explanation Texts Structure and Features of Explanation Texts, (Blake Education Fully Reproducible, 2011), 62-63.

\footnotetext{
${ }^{24}$ Blake, loc. Cit.
}

e. Language Features of Explanation Text

Many language use components

mostly should be considered to write an

explanation text as follow:

1) Use present tense as the text tells about an evidence. For example: The lungs, trachea, and nose trachea, and lungs are the central organs which shape up the respiratory system.

2) Use abstract nouns (phrases) as a subject or an object. For example:It all happens in the space of a single breath.

3) Use pronouns for words already introduced. For example:This oxygen is brought first in by the nose or mouth. It later moves into the trachea (the pharynx) and on within the voice box (the larynx).

4) Use action verb with its agreement. For example: The intercostal muscles push the rib cage back inwards.

5) Use adverbial phrases of time and place to tell when and where actions happen. For example: Amazon valley produces the world's oxygen by forty percent.

6) Use time sequence connectors, like first, then, after, etc. For example: After moving down the trachea, the oxygen goes into the lung underneath either the right or left bronchus.

7) Use passive voice to link the events through cause and effect. The bronchioles and alveoli are covered with small blood vessels called capillaries.

8) Use time conjunctions to keep the text flowing. Placing them in the beginning of sentence can hook reader's attention. For example: When a Tsunami comes, it hits everything like trees and building. ${ }^{25}$

${ }^{25}$ Blake, op. cit,. p. 62. 


\section{Methodology}

The design of this research has used quasi experimental design which focused on the non-equivalent control group. There were two classes in this design. They were experimental and control class. Both of the classes had pre-test and post-test, in experimental class there was a treatment after giving pre-test, while in control class there was no a treatment. The design of this research is proposed by Cresswell as follows:

\begin{tabular}{|c|c|c|c|}
\hline Group & $\begin{array}{c}\text { Pre- } \\
\text { test }\end{array}$ & Treatment & $\begin{array}{c}\text { Post- } \\
\text { test }\end{array}$ \\
\hline $\mathrm{E}$ & Test 1 & $\mathrm{X}$ & Test2 \\
\hline $\mathrm{C}$ & Test2 & - & Test2 \\
\hline
\end{tabular}

In which:

$\mathrm{E}=$ Experimental group

$\mathrm{C}=$ Control Group

$\mathrm{T} 1=$ Pre-test

$\mathrm{X}=$ Treatment

$\mathrm{T} 2=$ Post-test

The location of this research was at SMA Negeri 1 Kasimbar, Jln. Trans Sulawesi No 1 Kasimbar, Kec. Kasimbar.

The sample of this research are XI IPA 1 as the experimental class and XI IPA2 as the control class. To obtain the data needed, the writer administered test. The writer chose this technique to collect the data because this technique is easy to apply to the students. The test involved pre-test and post-test. This study was taken 8 meetings.

\section{Result and Discussion}

In this section, the writer described and discussed about the results of the research. This research was conducted in the middle of the Corona pandemic, and the eleventh-grade students did not carry out the learning process at school effectively, in another sense they did offline learning at the teacher houses in four villages. Where two villages as the control class and the other two villages as the experimental class. So that some activities of the learning process was briefly, such as the time allocation of learning in the previous was $2 \times 45$ minutes when the writer conducted the research.

In the first meeting of research, the writer gave the pre-test to the students. In the pre-test, there were no students either in the controlled class or the experimental class who passed the minimum of standard achievement KKM (70).

The writer applied the treatment ( choral reading technique) at the second meeting until the seventh meeting. In the last meeting, the writer gave the pre-test to the students. So, there were eight times of meeting's total for each class.

In the last meeting, the writer gave the post-test to the students. It aimed to measure the students reading comprehension after given the treatment. Based on the result of their post-test, it showed that in the controlled class, there were 8 students out of 21 who can pass the minimum of standard achievement 70 (KKM), while in the experimental class there were 15 students out of 21 who success to passed the KKM. It is clearly stated based on the result of t-counted that shows 3,729 that higher than t-table 2,023. It shows that the using of choral reading technique was effective to the eleventh grade students' reading mastery at SMA Negeri 1 Kasimbar.

\section{Conclusion and Suggestions}

\subsection{Conclusion}

Based on the result of this research, there was significant influence of using choral reading technique to the eleventh grade students' reading mastery at SMA Negeri 1 Kasimbar. It can be revealed from the result of the t-counted(3.729) was higher than the t- 
Datokarama English Education Journal Vol. 2 No. 2, 2021

table (2,023). It means that null hypothesis is rejected and alternative hypothesis is accepted. 5.2 Suggestion

In favor of increase the English teaching quality, the writer would like to give some suggestions as follows:

1. The teachers are suggested to apply choral reading technique as a variation in mastering the reading text which can help them to read better.

2. The students should read more in school or out of school.

3. The students should pay more attention when the teacher reads the text.

4. The headmaster is suggested to support the English learning process by preparing the facilitation and instrument completely. 
Datokarama English Education Journal Vol. 2 No. 2, 2021

\section{References}

AchmadDoddy, Ahmad Sugeng, and Effendi, Developing English Competencies 3: for Senior High School (SMA/MA) Grade XI of Natural and Social Science Programmes, (Jakarta: PusatPerbukuan, 2008)

Barbara J. Wendling and Nancy Mather, Essentials of Evidence, (Autralia: Wiley, 2008)

Blake, Explanation Texts Structure and Features of Explanation Texts, (Blake Education Fully Reproducible, 2011)

David Nunan, Practical English Language Teaching.(New York: McGraw Hill Companies Inc ,2005)

Hasbrouck, J. Choral Reading. from https://www.readingrockets.Org/strategi es/choral_reading. (2006).( accessed on 06 June, 2016).

http://www.sraonline.com

Hülya Kodan "The Effects of the Methods of Choral, repeated and Assisted reading on the Reading and Reading Comprehension Skills of Poor Readers",conducted under the supervision of Hawaii Akyol. Online published (Turkey: Bayburt University, Education Faculty, Departement of Primary Education, 2017)

J. Charles Alderson, Assesing Reading,(New York: Cambridge University Press, 2000),

Judie Haynes, Getting Started with English Language Learners, (USA: ASCD, 2007)
Judy Yoneoka. Choral Reading vs. Individual Oral and Silent Reading: Relative Validity of the Alternatives in the English Reading Classroom.[Electronic Version], Assessed on May 5, 2011, Unpublished)

Kathryn Freeman. Stuttering reduction During Choral Reading, journal of speechlanguage pathology and audiology. Journal of Speech-Language Pathology and Audiology, Vol .22, No.3, september 1998. 188.

Laura Garett. Choral Reading Strategy. [Electronic Version] fromhttp://myweb.stedwards./Ed/mikek b/ReadStrong/choralreading.html. (accessed on May 05, 2011)

Mahrukh Bashir, Bahasa Inggris: SMA/ MA/ SMK/ MAK Kelas XI, (Jakarta: Pusat Kurikulum dan Perbukuan, 2014)

Nadia Zorrela 'Increasing Students' Reading Comprehension Through Choral Reading Strategy at Seventh Grade of Private Islamic Junior High School Jami'Al Kautsar Tapung Hilir'. Online published (Medan: Departement of English Education Faculty of Tarbiyah and Teacher Training State Islamic University of North Sumatra Medan, 2017)

Sara J. Gervase. "Reading Mastery: A Descriptive Study of Teachers Attitudes and Perceptions Towards Direct Instruction. A Thesis, (Bowling Green University Graduate Student, 2005), 11

Sylvia Linan-Thompson and Sharon Vaughn, Research-Based Methods of Reading Instruction for English Language 
Datokarama English Education Journal Vol. 2 No. 2, 2021

Learners grades $K-4$ (USA: ASCD, 2007)

Zuchdi and Budiasih, The Nature of Reading, (Learning Media, http://jundanjin.blogspot.com/2011/01/ nature-of-reading.html, (accessed on December 06, 2019) 